Carrington maintained that the United Kingdom had always been in the lead in offering its research and development programme to the Organization. $\mathrm{He}$ said that Britain had recently proposed to accelerate progress by concentrating on a selected number of major weapon projects, some of which were already moving from the planning to the implementation stage. Referring to the establishment last November of the Atlantic Institute, the Earl of Dundonald said that considerable debate in Paris led to the conclusions that language was a major obstacle to furthering a real Atlantic Community, being particularly prejudicial to scientific co-operation. The sub-committee which reached this conclusion considered also that any modified organization should include from member countries high-level representation of education, scientific affairs, universities and sciontific research organizations. An Atlantic Plan for Youth had been suggested with the aim of promoting the study of languages and the exchange of students, teachers and youth leaders. A programme of scientific co-operation among the scientists and scientific institutions of the whole Community of the Organization was also proposed, and in particular it was hoped to abolish anomalies which prevented a. student taking his degree in another country and then returning to his own country to practise, as well as to encourage exchanges of teachers and research workers. All this was strongly supported by Baroness Elliot of Harwood, who also referred to the vital importance of information services and to the position of the under-developed countries and the need both to help them and to enable them to understand what were the aims of the free world.

\section{Dragon Reactor Pressure Vessel}

THE pressure vessel for the Organization for European Co-operation and Development hightemperature gas-cooled reactor experiment, Dragon, arrived at Southampton from Germany on February 25 , and was then transported to Winfrith, where it will be installed for the Atomic Energy Establishment. The vessel, manufactured in two parts by Mannesmann-Export G.m.b.H., Germany, to the standards of leak tightness used in high-vacuum techniques, is shaped like a gigantic bottle. The vessel weighs 48 tons and is made from mild steel 2 in. thick. It is $58 \mathrm{ft}$. high altogether, the bottom part $22 \mathrm{ft}$. long having a diameter of $11 \frac{1}{2} \mathrm{ft}$., the middle part $22 \mathrm{ft}$. having a diameter of $6 \frac{1}{2} \mathrm{ft}$., while the neck of the vessel has a diameter of $2 \mathrm{ft}$. The vessel is designed to operate with an internal gas pressure of $350 \mathrm{lb} . /$ sq. in. absolute, and a gas temperature against the walls of $350^{\circ} \mathrm{C}$. The Dragon Project, which is sponsored by the European Nuclear Energy Agency and was set up in 1959 (see Nature, 184, 24, 942; 1959), is staffed by an international team drawn from Austria, Denmark, the Euratom Countries, Norway, Sweden, Switzerland and the United Kingdom. The Project's two main objectives are to carry out a programme of research and development in connexion with high-temperature gas-cooled reactor systems and to develop, design, construct and operate a 20-MW. (thermal) high-temperature gas-cooled reactor experiment at the United Kingdom Atomic Energy Authority's Establishment at Winfrith, Dorset.

\section{The Colour Group (Great Britain)}

The Physical Society Colour Group was founded in 1941 to meet a widely felt need for a forum where problems of colour could be discussed. Since then it has developed into an authoritative body along several lines in keeping with the width of interest which its object commands. As a result of various administrative changes its coming of age coincides with a re-formation of the original group on an independent basis. It was incorporated a short time ago under the name the Colour Group (Great Britain), and continues the pursuit of all its previous activities under the chairmanship of Dr. R. W. G. Hunt. Membership is open to all who are interested in colour in its various applications, whether technical, scientific, artistic or psychological. Further information can be obtained from Mr. F. J. B. Wall, honorary secretary, the Colour Group (Great Britain), Ramsden Colour Laboratory, Ilford, Ltd., Brentwood, Essex.

\section{Heavy Mineral Prospecting}

THE systematic mineralogical study of heavy concentrates panned from alluvium has long been accepted as one of the most rewarding methods of exploration for ore deposits, and in recent years the application of these traditional techniques in the U.S.S.R. has resulted in such successes as the discovery of the Yakutian diamond fields. It is therefore not surprising that, despite the competing claims of geochemical prospecting procedures more capable of being operated by semi-skilled staffs, heavymineral analysis continues to attract much attention in Russian institutions. Of the half-dozen text-books on this topic lately issued in the U.S.S.R., two are particularly noteworthy. An excellently produced Atlas of Placer Minerals, by N. N. Trushkova and A. A. Kukharenko (Pp. 437. Moscow: Gosgeoltekhizdat, 1961. 60s.), presents 102 quarto plates, nearly all in colour, illustrating the appearance of 183 species of detrital minerals (principally economic minerals) as seen under the microscope, with an explanatory text in English, French and German as well as Russian. The work has been colour-printed in Budapest for the All-Union Geological Research Institute, and it is evidently intended as a prestige publication. It should prove useful to university departments and economic geologists alike. A companion monograph on the mineralogy of placers (Mineralogiya Rossypei, by A. A. Kukharenko. Pp. 318. Moscow: Gosgeoltekhizdat, 1961. 25s.), which is available in Russian only, provides a comprehensive compilation of the properties and techniques of identification of placer minerals, making crossreferences to the Atlas, together with a lengthy essay on the genesis of placer ore deposits in which, perhaps for the first time, due attention is given to the effect of climate on alluvial mineralogy.

\section{Awards for Study Abroad}

THE Department of Scientific and Industrial Research is offering up to one hundred awards to scientists and technologists for study abroad, either through its own scheme of awards or through the North Atlantic Treaty Organization science studentship and fellowship scheme. The awards, which will be tenable for two to three years at universities, colleges and other approved institutions in any part of the world, may be at either postgraduate studentship or postdoctoral fellowship level. Details of these awards are given in D.S.I.R. Studentships and Fellow. ships 1962 (H.M.S.O., 2s.), and application forms can bo obtained from the Department of Scientific and Industrial Research, State House, High Holborn, London, W.C.1. 